\title{
Staphylococcus aureus Nasal Carriage and Autoimmune Diseases: From Pathogenic Mechanisms to Disease Susceptibility and Phenotype
}

\author{
Fulvia Ceccarelli ${ }^{*}{ }^{\dagger}$, Carlo Perricone ${ }^{+} \mathbb{D}$, Giulio Olivieri, Enrica Cipriano, \\ Francesca Romana Spinelli ${ }^{\circ}$, Guido Valesini and Fabrizio Conti ${ }^{\circledR}$ \\ Lupus Clinic, Rheumatology, Dipartimento di Medicina Interna e Specialità Mediche, Sapienza Università di \\ Roma, 00161 Rome, Italy; carlo.perricone@gmail.com (C.P.); giulio.olivieri19@gmail.com (G.O.); \\ enrica.cipriano@gmail.com (E.C.); francescaromana.spinelli@uniroma1.it (F.R.S.); \\ guido.valesini@uniroma1.it (G.V.); fabrizio.conti@uniroma1.it (F.C.) \\ * Correspondence: fulviaceccarelli@gmail.com \\ + These authors contributed equally to this work.
}

Received: 30 September 2019; Accepted: 6 November 2019; Published: 11 November 2019

\begin{abstract}
The role of infective agents in autoimmune diseases (ADs) development has been historically investigated, but in the last years has been strongly reconsidered due to the interest in the link between the microbiome and ADs. Together with the gut, the skin microbiome is characterized by the presence of several microorganisms, potentially influencing innate and adaptive immune response. S. aureus is one of the most important components of the skin microbiome that can colonize anterior nares without clinical manifestations. Data from the literature demonstrates a significantly higher prevalence of nasal colonization in ADs patients in comparison with healthy subjects, suggesting a possible role in terms of disease development and phenotypes. Thus, in the present narrative review we focused on the mechanisms by which $S$. aureus could influence the immune response and on its relationship with ADs, in particular granulomatosis with polyangiitis, rheumatoid arthritis, and systemic lupus erythematosus.
\end{abstract}

Keywords: autoimmune diseases; Staphylococcus aureus; colonization; pathogenesis; phenotype

\section{Introduction}

The multifactorial etiology of autoimmune diseases (ADs) has been widely confirmed and in the last years several researches focused on the identification of environmental factors able to induce disease development in genetically susceptible individuals [1,2]. The role of infective agents has been historically investigated, in terms of disease pathogenesis but also as comorbidities related to immunosuppressant treatments [3,4]. This attention determined the identification of microorganisms directly involved in disease pathogenesis. This is the case of Porphyromonas gingivalis, characterized by the ability to induce citrullination, a post-translational modification playing a central role in rheumatoid arthritis (RA) development [5,6].

The link with infections has been strongly reconsidered in the last years since the role of the microbiome in $\mathrm{AD}$ pathogenesis has been identified [7]. The presence of dysbiosis in patients affected by immune-mediated diseases has been widely demonstrated [8]. In particular, qualitative modifications have been observed in the gut microbiome of different inflammatory diseases in comparison with healthy subjects. Certainly, more evidence is available for spondyloartrhitis, but some studies have confirmed this aspect also in RA and systemic lupus erythematosus (SLE) patients [8-11]. These modifications have been related to different disease phenotypes and activity degrees [9-11]. 
Despite the great attention focused on gut microbiome modifications, the microbial composition significantly varies across different body sites and microbial communities could be implicated in human health and diseases [12]. The attention to the skin microbiome derives from the evidence that the skin is the largest organ of human body, inhabited by a variety of microorganisms, such as bacteria, fungi and viruses. Many of these microorganisms are harmless or even beneficial to their host, protecting it from invasion by more pathogenic or harmful organisms [13]. Moreover, these different microbial communities could create specific ecological niches, helping in disease prevention or, conversely, contributing to disease development [13]. Exogenous and endogenous factors regulate the growth of particular microorganism families. Among these, we can mention host factors (sex, age), the environment (climate, geographical location), skin topography, immune system (previous exposures to microorganisms, inflammatory conditions) [14].

Interestingly, at a skin level, innate and adaptive immune responses could modulate the resident microbiome, but the microbiome could also influence the immune system [14]. The modification of the skin ecosystem could alter this balance, resulting in different pathogenic conditions. For instance, some bacterial species limit the growth of other bacteria by hydrolyzing sebum lipids to toxic fatty acids $[15,16]$. Similarly, large-sale alterations of skin microbial communities have been linked to several non-infectious diseases, such as atopic dermatitis, psoriasis, rosacea and acne [14].

Staphylococcus aureus (S. aureus) is one of the most important component of the skin microbiome, responsible for different infective diseases, with a great range of severity. Epidemiological data suggest for $S$. aureus strains a specific geo-spatial predominance, but clear associations with specific phenotypes have not been reported [17]. Moreover, asymptomatic S. aureus carriage could occur in $20-30 \%$ of the general population, with a prevalent localization in anterior nares; this prevalence significantly increases in patients affected by ADs [18].

Moving from these evidences, here we performed a narrative review focusing on the possible role of nasal carriage in ADs development and phenotypes. In particular, we aimed at reviewing the impact of $S$. aures colonization on the immune response and AD phenotypes. For this purpose, a literature search was done in PubMed, accessed via the National Library of Medicine PubMed interface (http://www.ncbi.nlm.nih.gov/pubmed). Firstly, PubMed was searched using the term "Staphylococcus aureus" in combination with (AND) "autoimmune diseases" OR "autoimmunity".

Secondly, the same PubMed research was combined with other terms, such as "pathogenesis" OR "immune response" OR "granulomatosis with polyangiitis" OR "rheumatoid arthritis" OR "systemic lupus erythematosus". Further relevant data were obtained from the reference lists of articles returned using these search terms.

\section{Staphylococcus aureus: General Aspects}

S. aureus is the most important species in the Staphylococcus genus. It is a Gram-positive, aerobe and facultative anaerobe bacterium, colonizing the human skin. S. aureus-related infections are widely spread and can be very serious, with a great variation in mortality, depending on type, virulence factors of involved strains and, finally, patients' characteristics [19]. Table 1 reports the different factors conferring virulence to this bacterium.

All these factors are relevant from an epidemiological and clinical point of view, contributing to the pathogenicity of S. aureus [19]. First of all, several surface structures can play a role by binding extracellular proteins, such as matrix molecules, thus facilitating the host colonization [17]. Moreover, up to 40 exotoxins have been described so far; they are characterized by specific properties, even though a similar structure has been described. They are able to induce $\mathrm{T}$ and $\mathrm{B}$ cells proliferation and the consequent production of different cytokines. Thus, these exotoxins could modulate the host immune system during S. aureus infection [21]. T cell superantigens (SAgs) represent the largest family produced by $S$. aureus, with strong resistance to proteolysis [22]. Moreover, SAg seems to be involved in antigen presenting cells, resulting in polyclonal $\mathrm{T}$ cell proliferation, followed by a state of anergy [22]. 
Table 1. Factors conferring virulence to $S$. aureus.

\begin{tabular}{|c|c|}
\hline & Resource \\
\hline Surface Structures [17] & $\begin{array}{l}\text { 1. Polysaccharide capsule } \\
\text { 2. Adhesins } \\
\text { 3. Protein A }\end{array}$ \\
\hline Exotoxins $[20,21]$ & $\begin{array}{ll}\text { 1. } & \text { Hemolysins }(\alpha, \beta, \gamma \text { and } \delta) \\
\text { 2. } & \text { Panton-Valentine leucocidin (PVL) } \\
\text { 3. } & \text { Epidermolytic toxin A, cromosomal, and B, plasmidic } \\
\text { 4. } & \text { Toxic shock syndrome toxin-1 (TSST-1) } \\
\text { 5. } & \text { Enterotoxins }\end{array}$ \\
\hline Exoenzymes [20] & $\begin{array}{ll}\text { 1. } & \text { Lipases } \\
\text { 2. } & \text { Coagulases } \\
\text { 3. } & \text { Nucleases } \\
\text { 4. } & \text { Staphylochinases } \\
\text { 5. } & \text { Ureases } \\
\text { 6. } & \text { Hyaluronate-lyases } \\
\text { 7. } & \text { Serine-proteases } \\
\text { 8. } & \text { Catalasys } \\
\text { 9. } & \text { Superoxide dismutases }\end{array}$ \\
\hline
\end{tabular}

Moreover, S. aureus produces other virulence factors displaying enzymatic properties. We can differentiate cofactors activating host zymogens from enzymes able to degrade tissue components [20]. In particular, exoenzymes-i.e., nucleases and proteases-act by cleaving and inactivating different molecules involved in host defense, such as complement factors, antimicrobial peptides, surface receptors. Nonetheless, other exoenzymes could modify endothelial and epithelial barriers by cell lysis and cleavage of junction proteins [20].

Additionally, the ability of forming biofilm should be considered. In fact, biofilms are crucial for the colonization of medical devices-such as prothesis or catheters-and contributes to S. aureus spread into hospital settings, also fostering the resistance to antimicrobial therapy [23].

S. aureus is one the most frequent cause of skin infections, but it could be responsible for other serious conditions [19]. We summarize these infections in Table 2.

Table 2. S. aureus related infections.

\begin{tabular}{cc}
\hline Infections & Details \\
\hline Skin and Soft Tissues Infections [24-28] & $\begin{array}{c}\text { From benign to life threating conditions (impetigo, cellulitis, } \\
\text { surgical sites infections, cutaneous abscesses, purulent cellulitis) }\end{array}$ \\
\hline Osteoarticular Infections [29-34] & Osteomyelitis, septic arthritis, prosthetic joint infections \\
\hline Pleuropulmonary Infections [35-38] & $\begin{array}{c}\text { Predominant role in hospital-acquired pneumonias in } \\
\text { comparison to community-acquired ones. }\end{array}$ \\
\hline Bacteremia [39-41] & Direct evolution of a local infection \\
\hline Meningitis [42-44] & Complication of a primary non-central nervous system infection \\
\hline Epidural Abscesses [45,46] & $\begin{array}{c}\text { Rare intracranial or spinal condition, recognized in USA as } \\
\text { second most common infection due to malpractice }\end{array}$ \\
\hline Toxic shock Syndrome [47-49] & $\begin{array}{c}\text { Sustained by super antigen-mediated process, linked to toxic } \\
\text { shock syndrome toxin-1, able to activate T-cells, with massive } \\
\text { cytokine release }\end{array}$ \\
\hline
\end{tabular}


Table 2. Cont.

\begin{tabular}{cc}
\hline Infective Endocarditis [50-52] & $\begin{array}{c}\text { Observed in a proportion of S. aureus infected patients ranging } \\
\text { from } 16 \% \text { to } 34 \%\end{array}$ \\
\hline Cardiac Devices Infections $[53,54]$ & $\begin{array}{c}\text { Directly occurring during implantation or indirectly via } \\
\text { haematogenous seeding from a distant source }\end{array}$ \\
\hline Intravascular Catheter Infections [55-57] & $\begin{array}{c}\text { Potentially leading to a bacterial spreading in the bloodstream, } \\
\text { configuring the so-called central line-associated blood stream } \\
\text { infection (mortality rate } 7-21 \%)\end{array}$ \\
\hline Urinary Tract Infections $[58,59]$ & Frequent in case of indwelling urinary catheter \\
\hline Septic Thrombophlebitis $[60,61]$ & Reported in up to $8 \%$ of all patients with bacteriema \\
\hline
\end{tabular}

Given this huge spectrum of infective phenotypes, it is easily understandable how S. aureus could be considered one of the most concerning existing pathogen.

\section{Staphylococcus aureus Nasal Carriage: Interplay with the Immune System}

Nasal swab cultures demonstrate that $20-30 \%$ of the healthy population is persistently colonized by S. aureus and 30\% are intermittently colonized [62,63]. The different risk among persistent and intermittent carriers was not enough defined. Nonetheless, data from the literature report a lower S. aureus-attributable mortality for colonized patients developing bacteremia than non-colonized subjects. This observation could suggest a staphylococcal-specific immune priming or immunomodulation occurring as a consequence of colonization, impacting on the outcome of infection [64].

The principal habitat for $S$. aureus is represented by the squamous epithelium in the anterior nares; nonetheless, the posterior nares could be colonized. This selected colonization site is probably related to the presence of several components on bacterium surface-such as clumping factor A and B-, able to directly interact with nasal epithelium, promoting adhesion [65].

The condition of carriage, potentially associated with an increased infective risk, results from a complex interplay between several host and bacterial factors [66]. The different involved factors are reported in Figure 1.

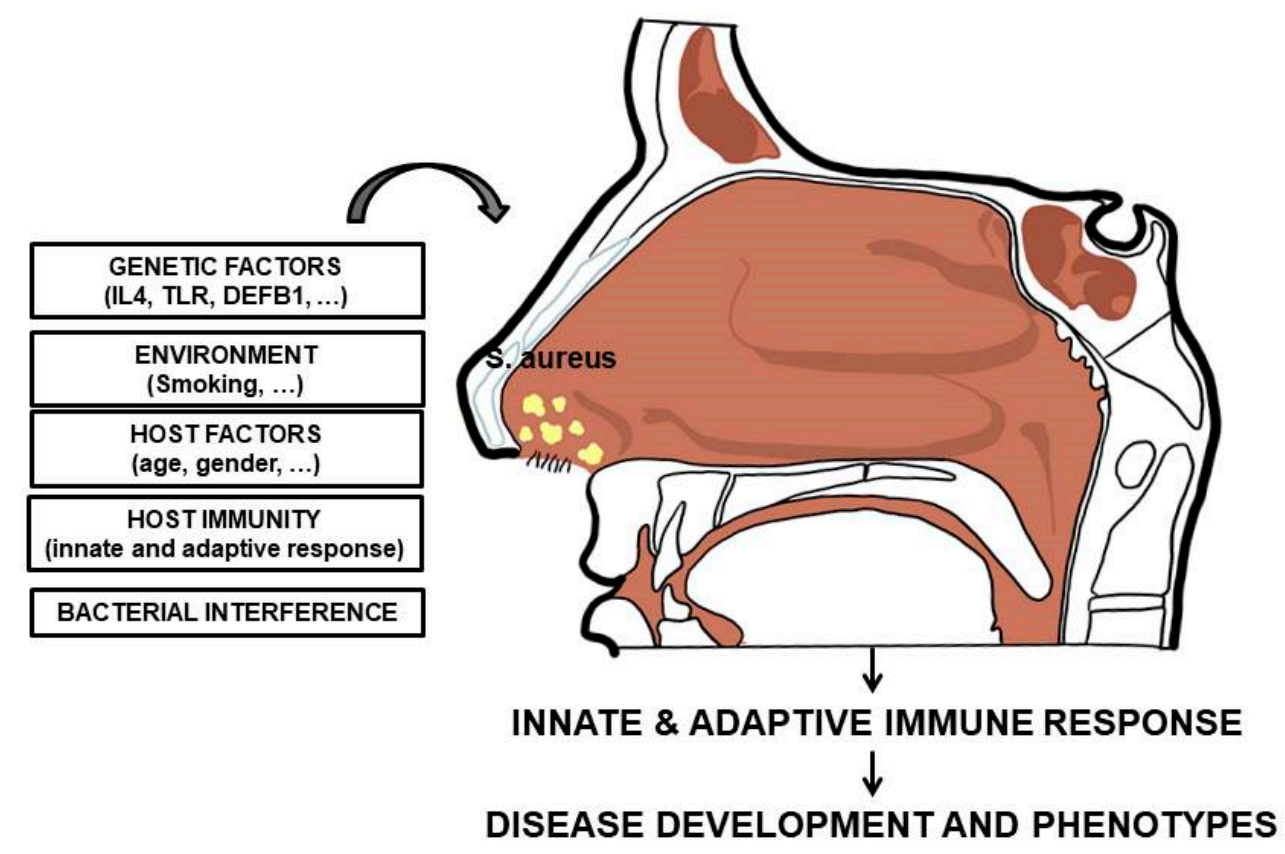

Figure 1. Host and bacterial factors influencing S. aureus nasal colonization. 
In particular, several indirect evidences suggested the connection between the host immune system and S. aureus nasal carriage. Certainly, a multitude of factors could mediate the equilibrium with the host immune response, but the specific mechanisms underlining this equilibrium is unknown. Specific polymorphisms on genes encoding for mannose-binding lectin, Toll-like receptor 2 (TL2), glucocorticoid receptor, $C$-reactive protein, $\beta$-defensin 1 promoter region and interleukin- 4 have been associated with this condition [67-73].

These associations underline the involvement of both innate and adaptive immunity during S. aureus colonization. Moreover, disease characterized by immune system depletion shows an increased incidence of colonization. For instance, this has been demonstrated in HIV patients, in which a CD4+ T cell depletion is observed, but also in patients affected by ADs treated by immunosuppressant drugs $[74,75]$.

Moving on to innate immunity, the epithelium barrier is the first line defense in the nose. In particular, keratinocytes could express several antimicrobial peptides, including LL-37 and $\beta$-defensin-3, as well as chemokines (i.e., IL8) and cytokines (IL6, TNF, IL10) [76-78].

Among antimicrobial peptides, human $\beta$-defensin- 3 is the most important peptide in terms of in vitro anti-bacterial effects and involvement in skin infection development. It is produced by the nasal epithelium in response to the presence of $S$. aureus or to skin barrier alterations, suggesting a role in bacterium clearance in colonized and infective patients. Nonetheless, persistent carriers subjects show reduced level of this antimicrobial peptide in comparison with non-carriers [76,78-80].

Furthermore, LL-37 shows a strong in vitro killing effect on $S$. aureus: however, similar to that observed for human $\beta$-defensin-3, higher level of LL-37 have been observed in colonized patients [81,82].

At this level, TL2 plays a crucial role for keratinocyte-mediated S. aureus recognition, leading to immune response activation, with $\mathrm{T}$ cell recruitment [80]. In details, as widely demonstrated, TLR2 acts by recruiting intracellular TIRAP, MyD88, IRAK-1 and 4, leading to the activation of two different pro-inflammatory pathways-specifically, NF- $\mathrm{kB}$ and MAPKs. These processes translate into the production of pro-inflammatory cytokines and chemokines, crucial to recruit effector $\mathrm{T}$ cells, in particular Th1 and Th17 [83]. Interestingly, Parker and colleagues in 2012 suggested the possible role of TLR9 as a critical receptor mediating the induction of type I IFN signaling in dendritic cells in response to S. aureus colonization [84]. These results, confirmed by Parcina et al. in 2013, demonstrated an additional mechanism by which $S$. aureus could influence the innate immune response to infections [85]. However, neutrophils represent the first line cells intervening in S. aureus clearance: the bacterium is eliminated by phagocytosis and destroyed by hypochloric acid and oxygen radicals. Furthermore, activated neutrophils could release DNA into the extracellular matrix to produce neutrophil extra traps (NETs), enhancing the cytotoxicity of antimicrobial agents. Following the uptake of bacteria, neutrophils typically undergo apoptosis and are cleared by macrophages, resulting in microbe clearance [86,87].

More recently, several pieces of evidence have suggested that neutrophils and macrophages are in fact not able to kill all bacteria, and that $S$. aureus could proliferate at an intracellular level. In particular, a reduced number of bacteria were not removed from blood and remained localized in the neutrophils and could play a role in bacterial dissemination. Studies conducted on murine models and humans demonstrated the ability of $S$. aureus to survive in neutrophils, suggesting the so-called "Trojan Horse" theory of dissemination [88]. Moreover, S. aureus has been demonstrated able to survive in other cells, in particular macrophages and endothelial cells $[89,90]$.

The dissemination occurs in two phases: in the first one, $S$. aureus bacteria replicate and escape from the macrophages by lysis during the first $24 \mathrm{~h}$ of infection. In the second phase, bacterial levels increase in organs other than the liver, such as the kidneys [91]. Figure 2 summarizes the interactions between the nasal epithelium and immune responses. 


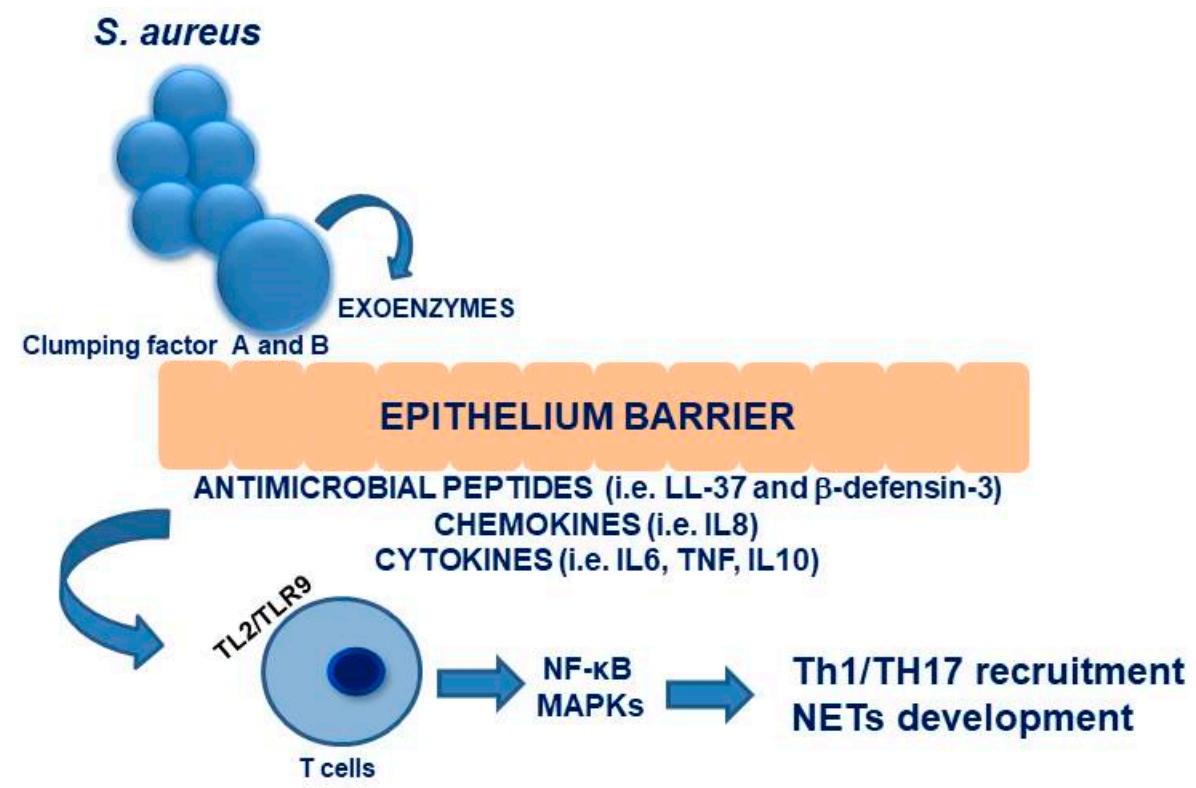

Figure 2. Schematic representation of interactions between nasal epithelium and immune response.

As recently demonstrated, pathogens could activate specific transcriptional pathways interfering with host defense mechanism. Several efforts have been made to identify the role of these new pathways in S. aureus infections. Among these, the pathway involving activation of Stimulator of IFN Genes (STING) has been identified. STING play a key role in the host immune response, by exerting the recognition of nucleotide and allowing the identification of different microorganisms [92].

In particular, STING is able to recognize cyclic dinucleotides or, in association with intracellular sensors, DNA from bacteria, viruses and host cells, in order to control the host immune responses [93]. Several lines of evidence have demonstrated STING functions during viral infections; conversely few data are available about its possible role in bacterial pathogenesis [94]. Nonetheless, the STING activation, leading to IFN $\beta$ production, may be beneficial or detrimental for the host according to the specific infection. The role of STING depends on the influence of cyclic dinucleotides in bacterial metabolism, such as biofilm formation and protein function [95]. Concerning the possible role of STING pathways in S. aureus infection, Sciumpia and colleagues suggested that TLR and STING pathways could play opposite roles in host defense against this bacterium, by using a cutaneous infection model. In fact, the lack of TLR signaling leads to a reduced production of IL- $1 \beta$ and neutrophil recruitment. In contrast, the absence of STING signaling enhances the ability to restrict the infection. Thus, the authors hypothesized that opposing roles of TLR and STING could play a key role in the complex interplay of innate immune signaling pathways triggered by S. aureus [96].

Contrary to these data about innate immunity, the development of an adaptive immunological response to $S$. aureus is not fully understood and still remains unclear. However, some studies have observed a different humoral immune response by comparing carrier and non-carrier $S$. aureus subjects. In particular, carrier subjects shown higher serum IgG titres, higher median levels of IgA for several staphylococcal proteins, and higher titres of neutralising antibodies to superantigens specifically expressed by their resident strain [97-99]. However, the mechanism by which S. aureus colonization could induce a humoral response has not been clarified. This specific aspect of immunological response to $S$. aureus is very intriguing in the light of possible development of vaccines against this bacterium.

\section{Staphylococcus aureus and Granulomatosis with Polyangiitis}

Granulomatosis with polyangiitis (GPA) is a small-vessel vasculitis characterised by granulomatous inflammation, involving hebupper respiratory tract (URT) and lower respiratory tract. The URT involvement determined the interest on the possible role of nose microbiome on disease pathogenesis, 
with particular attention on S. aureus carriage. Up to $80 \%$ of GPA patients shows the involvement of nasal mucosa, often as first involved site before the development of a systemic autoimmune vasculitis, characterized by the positivity for specific anti-neutrophil cytoplasmic autoantibodies directed against proteinase 3 [100].

From an epidemiological point of view, a nasal S. aureus carriage condition is significantly more frequent in GPA patients than healthy individuals and patients with chronic rhinosinusitis [101]. In particular, $60-70 \%$ of GPA patients are chronic nasal carrier for S. aureus, compared with $20-30 \%$ of healthy subjects [102-104]. Moreover, this bacterium seems to play a role in determining disease relapses [105]. Stegeman and collegues in 1994 analysed 71 biopsy-proven GPA subjects, showing that S. aureus nasal carrier patients were more prone to disease relapse. In particular, the risk of disease relapses has been described seven times higher in chronic nasal carriers [53]. This result was confirmed by Zycinska and colleagues in 2008, showing a 4.5-fold risk for relapse in limited GPA [103].

Finally, this association has not been definitively confirmed, as demonstrated by the study published by Laudien et al., showing only a trend for a higher relapse rate [100], in agreement with previous data deriving from a Norwegian cohort [105]. More recently, a multicentre prospective study conducted by Salmela and colleagues, including 73 newly diagnosed GPA, demonstrated a significantly higher relapse rates in chronic S. aureus carriers [106].

To support the association between $S$. aureus colonization and disease flare-ups, two randomized clinical trials demonstrated the ability of treatment with trimethoprim-sulfamethoxazole in preventing relapses [106,107]. The beneficial effect of antibiotic treatment has been demonstrated especially in GPA patients with localized disease but not in those with a systemic involvement $[105,106]$.

The study recently published by Rhee and colleagues aimed at examining the entire community of nasal bacteria and fungi in 60 GPA patients and 41 healthy controls. S. aureus, S. epidermidis, Corynebacterium tuberculostearicum, and Propionibacterium acnes, resulted the most prominent bacterial species in the GPA nasal cavities. The authors identified a significant difference in weighted UniFrac between GPA participants and healthy controls, suggesting a different microbial composition between the two groups [108]. More recently, Lamprecht and colleagues evaluated the samples from nasal cavities by 29 GPA, 21 RA patients, and 27 healthy controls; the authors performed a 16S rRNA amplicon sequencing comparing nasal microbiome in patients and controls, showing a trend for a reduced diversity and a decrease in taxonomic abundance and microbial richness in the samples from GPA compared with RA patients. Finally, alpha diversity-defined as mean species diversity in sites or habitats-resulted reduced in GPA patients with active disease in comparison with patients showing a remission status. GPA and RA patients displayed similarities at the family levels, in particular increased abundance of Planococcaceae, but also some differences in microbial composition. In fact, GPA patients showed abundance of Prevotellaceae in comparison with RA. The authors concluded that both immunosuppressive status and disease background could influence the URT microbiome composition. The analysis of GPA patients revealed that bacterial composition at the phylum, class and family level was not different according disease activity status, except for the Staphylococcaceae family, resulting more abundant in remission condition. The application of qPCR demonstrated a significant higher proportion of S. aureus in GPA patients than in RA and healthy controls [109].

Taken together, these data suggested an unbalanced composition of the nasal microbial flora, that could contribute as environmental factor by interacting with a susceptible genetic background, determining disease development and phenotype. Thus, moving on to a disease-related pathogenic scenario, GPA-related granulomatous lesions are characterized by the presence of ectopic lymphoid structures, suggesting the development of an antigen-driven inflammatory response at this level $[110,111]$. Moreover, the barrier dysfunction and the modification of mucociliary clearance identified in GPA subjects could be associated with the occurrence of dysbiosis [109]. Several studies have investigated the possible mechanisms by which $S$. aureus carriage could play a role in disease development and phenotypes. First of all, its role on the dysbiosis has been suggested, involving the 
reduced secretion of human $\beta$-defensin-3, an epithelial defensin displaying a high activity against S. aureus [112].

Moreover, the role of Staphylococcus superantigens (SAg) has been investigated. This term refers to a group of antigens that are able to induce global changes in the lymphocyte repertoire, by stimulating more than $5 \%$ of the naive lymphocyte pool. In particular, these exotoxins shown a strong ability to stimulate T cells in a non-antigen way. To date, three classes of SAg have been described-staphylococcal enterotoxins, exfoliative toxins and toxic-shock syndrome toxin 1 (TSST-1) [113-115].

Popa and colleagues observed an increased risk to relapse in S. aureus carriers producing the superantigen TSST-1 [102]. Conversely, Fijolek and colleagues identified the presence of at least one SAg in $34.8 \%$ of GPA patients, but its presence was not associated with disease activity. However, earlier studies had not revealed a correlation between the presence of SAg genes and the expansion of specific $T$ cell subsets in peripheral blood [116].

The role of $S$. aureus as a trigger in GPA development has been reconsidered in the last decade, underlining that it could be difficult to distinguish between causality and consequence of S. aureus carriage in determining GPA pathological setting. In 2011, Laudien and colleagues evaluated the molecular signatures at the nasal barrier level of a cohort of GPA patients, compared with healthy controls. The authors identified specific GPA-associated molecular profiles; in particular, ten transcripts differentially expressed between case and controls. These transcripts include antimicrobial peptides (human-defensin, lysozyme, DEFB4, S100A7), innate immune receptors (TLR4, NOD-like receptor, C3, CD36), and cytokines (IFN $\gamma$, TGF 31 , IL17D). Interestingly, these transcriptional profiles resulted independent from S. aureus colonization, as demonstrated by the reduction of the number of significantly dysregulated transcripts in carriers. The authors speculated about a secondary role of S. aureus colonization, representing a consequence of initially disturbed nasal barrier function rather than a causative event starting pathological cascade. Moreover, impaired lysozyme expression in GPA patients could promote $S$. aureus colonization; thus, the upregulation of $\beta$-defensin family members, might represent a direct antibacterial response and an attempt to restore immunological barrier function [117].

More recently, Wohlers and colleagues aimed to evaluate the ability of S. aureus to influence the nasal microenvironment's cytokine secretion. The authors identified an altered baseline cytokine pattern in GPA subjects, with up-regulation of G-CSF and reduction in IL-8 concentrations. Both nasal epithelial cells from GPA and controls responded to S. aureus stimulation, but a significantly lower IL-8 secretion and a reduced dynamic range of response to the stimulus was observed in GPA patients. Therefore, the study suggested that the dysregulation of baseline expression of G-CSF and IL- 8 and the reduced response to microbial stimulation could modify the composition of the nasal microbiome and favour an imbalanced inflammatory response, potentially relevant for the disease course [118].

Finally, Glasner and colleagues in 2015 analyzed serum antibody levels against a comprehensive antigens set of $S$. aureus, in order to evaluate humoral immune response against this bacterium. The authors observed that GPA sera contained lower anti-staphylococcal IgG levels than controls, regardless of the treatment assumed. These results could suggest that GPA patients could be less capable of mounting a potentially protective antibody response to $S$. aureus than healthy individuals. Furthermore, the evaluation of 210 S. aureus isolates from GPA patients demonstrated a higher diversity, mirroring the general S. aureus population [69]. The same authors investigated the gene repertoire of S. aureus nasal isolates from PR3-ANCA-positive patients, by performing a comparison between $S$. aureus isolates from MPO-ANCA-positive patients and from healthy controls. The MPO-ANCA-associated S. aureus isolates resulted different from healthy controls and PR3-ANCA-associated isolates. Furthermore, several genetic loci of S. aureus are associated with either PR3-ANCA- or MPO-ANCA-positive ANCA associated vasculitis, indicating a possible role for pore-forming toxins in PR3-ANCA-positive GPA [119]. 


\section{Staphylococcus aureus and Other Autoimmune Diseases}

Behind the GPA, the possible role of $S$. aureus carriage condition has been investigated in other ADs, in particular RA and SLE, even though without reaching conclusive results. As widely observed, RA patients are five-times more likely to die for pneumonia, have a 10-15 times greater risk for bone and joint infections and are three times more likely to suffer skin infections than the general population [120]. This risk seems to be higher in patients treated with biological drugs, in particular TNF antagonists. This could be related to the role of TNF in the innate immune response to both intra and extracellular infections, including S. aureus [121-124].

Few studies-with limited sample size-have evaluated the prevalence of $S$. aureus nasal colonization in RA cohorts, describing a prevalence of $50-56 \%$, similar to that identified in control subjects [32,125]. Varley et al. in 2013 evaluated a large cohort of patients affected by different immune-mediated inflammatory diseases-RA $28.1 \%$; psoriasis/psoriatic arthritis $52 \%$; ankylosing spondylitis $6.6 \%$; other diseases $11.1 \%$. More than half of enrolled patients $(52.0 \%)$ were taking biologic therapy at the first assessment ( $92.6 \%$ of them were on TNF inhibitor treatment). At the enrolment, $40.0 \%$ of patients were $S$. aureus carriers, with $12.3 \%$ of patients showing methicillin-resistant S. aureus. The colonization prevalence in anti-TNF treated patients was similar than that observed in non-treated patients; however, this prevalence is significantly higher in psoriasis subjects than RA. A follow-up evaluation was performed in $70 \%$ of patients after a median interval of 0.63 years: subjects colonized at baseline were more likely to be colonized also at the follow-up, especially if treated with anti-TNF during this period (OR 2.2) [125]. More recently, Goodman and colleagues observed that RA patients treated by biological drugs showed a statistically significant increase in S. aureus colonization (37\%) compared to RA on DMARDs alone $(24 \%)$, or control subjects affected by osteoarthritis $(20 \%)$. This result was confirmed at logistic regression analysis, after correction for glucocorticoids and antibiotic treatment, recent hospitalization, and diabetes [126]. In RA cohort, $28 \%$ of patients was treated by adalimumab, $25.2 \%$ by etanercept, $12.2 \%$ by abatacept, and $12.2 \%$ by rituximab. However, no data about SA colonization rate in the different biological treatments were provided in the study [126].

From a pathogenic point of view, data about the role of $S$. aureus in RA development are lacking. However, Ataee and colleagues in 2014 performed a study to detect staphylococcal enterotoxin C in synovial fluid of $50 \mathrm{RA}$ patients. In the evaluated cohort, bacterial culture was negative in all samples, but interestingly, $66 \%$ of analysed samples contained staphylococcal enterotoxin $C$ gene. Moreover, enterotoxin $C$ was detected in $46 \%$ of synovial fluid [127]. The same authors also evaluated the enterotoxin D levels in 120 blood and synovial fluid samples from RA patients: in particular the authors performed bacterial DNA extraction from blood buffy coat and from synovial fluid. The study demonstrated entD gene in $50 \%$ of patient's synovial fluid and $37.5 \%$ of blood buffy coat. Moreover, the ELISA test demonstrated staphylococcal enterotoxin D in $36.16 \%$ of analyzed synovial fluid and $33.33 \%$ of blood buffy coat [128]. These results could suggest a possible role of S. aureus in RA development, but certainly other studies are needed to confirm this suggestion.

Moving on to SLE, a chronic autoimmune disease potentially involving any organ/system, infections resulted highly associated with the disease onset but also with disease flare-ups [129]. Several studies have suggested the possible pathogenic role of different infective agents, in particular Epstein-Barr virus, parvovirus B19, retrovirus, and cytomegalovirus [130,131]. In fact, the prevalence of these infections has been proved significantly higher in SLE cohorts in comparison with healthy subjects. The abovementioned viruses could activate a self-directed immune response, influencing disease development and course [132,133].

Few data are available concerning the possible role of bacteria in SLE pathogenesis. Concerning S. aureus, in 2012 Chowdhary and colleagues performed a study on HLA-DQ8 transgenic mice subcutaneously implanted with mini-osmotic pumps, capable of continuously delivering the Sag or staphylococcal enterotoxin B. Chronic exposure to the latter resulted in a multisystem autoimmune inflammatory disease similar to SLE, as demonstrated by mononuclear cell infiltration of lungs, liver, 
and kidneys, associated with the production of anti-nuclear antibodies and deposition of immune complexes at renal level. The identified inflammatory infiltrates predominantly included of CD4+ T cells. Thus, this study suggests the possible etiological role of chronic exposure to antigen bacterial [133].

To the best of our knowledge only one paper, published by our research group, has focused on S. aureus nasal colonization in SLE patients. In this study, we enrolled 84 SLE patients and 154 healthy subjects, showing a similar colonization prevalence in case and controls $(21.4 \%$ versus $28.6 \%$ ). By dividing patients according to the presence of nasal S. aureus, we identified a specific clinical and serological profile in positive patients, characterized by presence of several autoantibodies (anti-dsDNA, anti-Sm, anti-SSA, anti-SSB, anti-RNP) and renal and skin manifestations [134]. It could be hypothesized that $S$. aureus carriage status, by stimulating the type-I IFN pathway, could induce the production of autoantibodies and therefore the development of the previously mentioned clinical manifestations [135]. Indeed, pathogen-recognizing dendritic cells could activate T cells and take up S. aureus through an endocytic mechanism, resulting in the activation of TLR9 signaling [84].

\section{Conclusions}

In the present review, we have focused on the possible role of $S$. aureus nasal colonization on $\mathrm{AD}$ development and phenotype. Behind the development of infective diseases with different degrees of severity, $S$. aureus colonization seems to be able to modulate the immune system both in terms of its innate and adaptive responses. Based on these premises, literature data underlines the role of this bacterium firstly in patients affected by GPA from a pathogenic and disease phenotype point of view. Moreover, few data suggest the possible role also in other ADs, such as RA and SLE. Other studies, focusing on these patients, are needed in order to confirm these preliminary suggestions. In conclusion, data from the literature suggest that the assessment of a state of colonization must be taken into consideration especially in specific populations, such as patients affected by ADs treated by immunosuppressant treatments. Further studies are needed in order to evaluate the modifications determined by S. aureus colonization in ADs and the impact of bacterium eradication in disease course.

Funding: This research received no external funding.

Conflicts of Interest: The authors declare no conflict of interest.

\section{Abbreviations}

Autoimmune diseases

Rheumatoid arthritis

Systemic lupus erythematosus

Staphylococcus aureus

Toll-like receptor 2

Stimulator of IFN Genes

Granulomatosis with polyangiitis

Upper respiratory tract
ADs
RA
SLE
S. aureus
TL2
STING
GPA
URT

\section{References}

1. Ceccarelli, F.; Perricone, C.; Borgiani, P.; Ciccacci, C.; Rufini, S.; Cipriano, E.; Alessandri, C.; Spinelli, F.R.; Sili Scavalli, A.; Novelli, G.; et al. Genetic Factors in Systemic Lupus Erythematosus: Contribution to Disease Phenotype. J. Immunol. Res. 2015, 2015, 745647. [CrossRef] [PubMed]

2. Perricone, C.; Ciccacci, C.; Ceccarelli, F.; Di Fusco, D.; Spinelli, F.R.; Cipriano, E.; Novelli, G.; Valesini, G.; Conti, F.; Borgiani, P. TRAF3IP2 gene and systemic lupus erythematosus: Association with disease susceptibility and pericarditis development. Immunogenetics 2013, 65, 703-709. [CrossRef] [PubMed]

3. Bach, J.F. Infections and autoimmune diseases. J. Autoimmun. 2005, 25, 74-80. [CrossRef]

4. Conti, F.; Ceccarelli, F.; Massaro, L.; Cipriano, E.; Di Franco, M.; Alessandri, C.; Spinelli, F.R.; Scrivo, R. Biological therapies in rheumatic diseases. Clin. Ther. 2013, 164, e413-e428. 
5. Mastrangelo, A.; Colasanti, T.; Barbati, C.; Pecani, A.; Sabatinelli, D.; Pendolino, M.; Truglia, S.; Massaro, L.; Mancini, R.; Miranda, F.; et al. The Role of Posttranslational Protein Modifications in Rheumatological Diseases: Focus on Rheumatoid Arthritis. J. Immunol. Res. 2015, 2015, 712490. [CrossRef] [PubMed]

6. Perricone, C.; Ceccarelli, F.; Saccucci, M.; Di Carlo, G.; Bogdanos, D.P.; Lucchetti, R.; Pilloni, A.; Valesini, G.; Polimeni, A.; Conti, F. Porphyromonas gingivalis and rheumatoid arthritis. Curr. Opin. Rheumatol. 2019, 31, 517-524. [CrossRef] [PubMed]

7. Coit, P.; Sawalha, A.H. The human microbiome in rheumatic autoimmune diseases: A comprehensive review. Clin. Immunol. 2016, 170, 70-79. [CrossRef]

8. Shin, C.; Kim, Y.K. Autoimmunity in microbiome-mediated diseases and novel therapeutic approaches. Curr. Opin. Pharmacol. 2019, 49, 34-42. [CrossRef]

9. Brusca, S.B.; Abramson, S.B.; Scher, J.U. Microbiome and mucosal inflammation as extra-articular triggers for rheumatoid arthritis and autoimmunity. Curr. Opin. Rheumatol. 2014, 26, 101-107. [CrossRef]

10. Katz-Agranov, N.; Zandman-Goddard, G. The microbiome and systemic lupus erythematosus. Immunol. Res. 2017, 65, 432-437. [CrossRef]

11. Yacoub, R.; Jacob, A.; Wlaschin, J.; McGregor, M.; Quigg, R.J.; Alexander, J.J. Lupus: The microbiome angle. Immunobiology 2018, 223, 460-465. [CrossRef] [PubMed]

12. Sanford, J.A.; Gallo, R.L. Functions of the skin microbiota in health and disease. Semin. Immunol. 2013, 25, 370-377. [CrossRef] [PubMed]

13. Chiller, K.; Selkin, B.A.; Murakawa, G.J. Skin microflora and bacterial infections of the skin. J. Investig. Dermatol. Symp. Proc. 2001, 6, 170-174. [CrossRef] [PubMed]

14. Grice, E.A.; Segre, J.A. The skin microbiome. Nat. Rev. Microbiol. 2011, 9, 244-253. [CrossRef] [PubMed]

15. Puhvel, S.M.; Reisner, R.M.; Amirian, D.A. Quantification of bacteria in isolated pilosebaceous follicles in normal skin. J. Invest. Dermatol. 1975, 65, 525-531. [CrossRef]

16. Ulrich, R.G. Evolving superantigens of Staphylococcus aureus. FEMS Immunol. Med. Microbiol. 2000, $27,1-7$. [CrossRef]

17. Lowy, F.D. Staphylococcus aureus infections. N. Engl. J. Med. 1998, 339, 520-532. [CrossRef]

18. Mehraj, J.; Witte, W.; Akmatov, M.K.; Layer, F.; Werner, G.; Krause, G. Epidemiology of Staphylococcus aureus Nasal Carriage Patterns in the Community. Curr. Top. Microbiol. Immunol. 2016, 398, 55-87.

19. Tong, S.Y.; Davis, J.S.; Eichenberger, E.; Holland, T.L.; Fowler, V.G., Jr. Staphylococcus aureus infections: Epidemiology, pathophysiology, clinical manifestations, and management. Clin. Microbiol. Rev. 2015, 28, 603-661. [CrossRef]

20. Tam, K.; Torres, V.J. Staphylococcus aureus Secreted Toxins and Extracellular Enzymes. Microbiol. Spectr. 2019, 7. [CrossRef]

21. Kusch, H.; Engelmann, S. Secrets of the secretome in Staphylococcus aureus. Int. J. Med. Microbiol. 2014, 304, 133-141. [CrossRef] [PubMed]

22. Spaulding, A.R.; Salgado-Pabón, W.; Kohler, P.L.; Horswill, A.R.; Leung, D.Y.; Schlievert, P.M. Staphylococcal and streptococcal superantigen exotoxins. Clin. Microbiol. Rev. 2013, 26, 422-447. [CrossRef] [PubMed]

23. Weigel, L.M.; Donlan, R.M.; Shin, D.H.; Jensen, B.; Clark, N.C.; McDougal, L.K.; Zhu, W.; Musser, K.A.; Thompson, J.; Kohlerschmidt, D.; et al. High-level vancomycin-resistant Staphylococcus aureus isolates associated with a polymicrobial biofilm. Antimicrob. Agents Chemother. 2007, 51, 231-238. [CrossRef] [PubMed]

24. Que, Y.A.; Moreillon, P. Infective endocarditis. Nat. Rev. Cardiol. 2011, 8, 322-336. [CrossRef] [PubMed]

25. Davis, S.L.; Perri, M.B.; Donabedian, S.M.; Manierski, C.; Singh, A.; Vager, D.; Haque, N.Z.; Speirs, K.; Muder, R.R.; Robinson-Dunn, B.; et al. Epidemiology and outcomes of community-associated methicillin-resistant Staphylococcus aureus infection. J. Clin. Microbiol. 2007, 45, 1705-1711. [CrossRef] [PubMed]

26. Miller, L.G.; Perdreau-Remington, F.; Rieg, G.; Mehdi, S.; Perlroth, J.; Bayer, A.S.; Tang, A.W.; Phung, T.O.; Spellberg, B. Necrotizing fasciitis caused by community-associated methicillin-resistant Staphylococcus aureus in Los Angeles. N. Engl. J. Med. 2005, 352, 1445-1453. [CrossRef]

27. Ruhe, J.J.; Smith, N.; Bradsher, R.W.; Menon, A. Community-onset methicillin-resistant Staphylococcus aureus skin and soft-tissue infections: Impact of antimicrobial therapy on outcome. Clin. Infect. Dis. 2007, 44, 777-784. [CrossRef] 
28. Guidance for Industry. Acute Bacterial Skin and Skin Structure Infections: Developing Drugs for Treatment; Center for Drug Evaluation and Research, US Department of Health and Human Services, FDA: Washington, DC, USA, 2013. Available online: http://www.fda.gov/downloads/Drugs/ (accessed on 30 September 2019).

29. Sheehy, S.H.; Atkins, B.A.; Bejon, P.; Byren, I.; Wyllie, D.; Athanasou, N.A.; Berendt, A.R.; McNally, M.A. The microbiology of chronic osteomyelitis: Prevalence of resistance to common empirical anti-microbial regimens. J. Infect. 2010, 60, 338-343. [CrossRef]

30. Torda, A.J.; Gottlieb, T.; Bradbury, R. Pyogenic vertebral osteomyelitis: Analysis of 20 cases and review. Clin. Infect. Dis. 1995, 20, 320-328. [CrossRef]

31. Mylona, E.; Samarkos, M.; Kakalou, E.; Fanourgiakis, P.; Skoutelis, A. Pyogenic vertebral osteomyelitis: A systematic review of clinical characteristics. Semin. Arthritis Rheum. 2009, 39, 10-17. [CrossRef]

32. Kaandorp, C.J.; Van Schaardenburg, D.; Krijnen, P.; Habbema, J.D.; van de Laar, M.A. Risk factors for septic arthritis in patients with joint disease. A Prospective Study. Arthritis Rheum. 1995, 38, 1819-1825. [CrossRef] [PubMed]

33. Liu, C.; Bayer, A.; Cosgrove, S.E.; Daum, R.S.; Fridkin, S.K.; Gorwitz, R.J.; Kaplan, S.L.; Karchmer, A.W.; Levine, D.P.; Murray, B.E.; et al. Clinical practice guidelines by the infectious diseases society of america for the treatment of methicillin-resistant Staphylococcus aureus infections in adults and children. Clin. Infect. Dis. 2011, 52, e18-e55. [CrossRef] [PubMed]

34. Lora-Tamayo, J.; Murillo, O.; Iribarren, J.A.; Soriano, A.; Sánchez-Somolinos, M.; Baraia-Etxaburu, J.M.; Rico, A.; Palomino, J.; Rodríguez-Pardo, D.; Horcajada, J.P.; et al. A large multicenter study of methicillin-susceptible and methicillin-resistant Staphylococcus aureus prosthetic joint infections managed with implant retention. Clin. Infect. Dis. 2013, 56, 182-194. [CrossRef] [PubMed]

35. Kollef, M.H.; Shorr, A.; Tabak, Y.P.; Gupta, V.; Liu, L.Z.; Johannes, R.S. Epidemiology and outcomes of health-care-associated pneumonia: Results from a large US database of culture-positive pneumonia. Chest 2005, 128, 3854-3862. [CrossRef]

36. Lee, M.S.; Walker, V.; Chen, L.F.; Sexton, D.J.; Anderson, D.J. The epidemiology of ventilator-associated pneumonia in a network of community hospitals: A prospective multicenter study. Infect. Control. Hosp. Epidemiol. 2013, 34, 657-662. [CrossRef]

37. DeRyke, C.A.; Lodise, T.P., Jr.; Rybak, M.J.; McKinnon, P.S. Epidemiology, treatment, and outcomes of nosocomial bacteremic Staphylococcus aureus pneumonia. Chest 2005, 128, 1414-1422. [CrossRef]

38. Torres, A.; Ferrer, M.; Badia, J.R. Treatment guidelines and outcomes of hospital-acquired and ventilatorassociated pneumonia. Clin. Infect. Dis. 2010, 51 (Suppl. 1), S48-S53. [CrossRef]

39. Laupland, K.B.; Ross, T.; Gregson, D.B. Staphylococcus aureus bloodstream infections: Risk factors, outcomes, and the influence of methicillin resistance in Calgary, Canada, 2000-2006. J. Infect. Dis. 2008, 198, 336-343. [CrossRef]

40. Kaasch, A.J.; Barlow, G.; Edgeworth, J.D.; Fowler, V.G., Jr.; Hellmich, M.; Hopkins, S.; Kern, W.V.; Llewelyn, M.J.; Rieg, S.; Rodriguez-Baño, J.; et al. Staphylococcus aureus bloodstream infection: A pooled analysis of five prospective, observational studies. J. Infect. 2014, 68, 242-251. [CrossRef]

41. Fowler, V.G., Jr.; Olsen, M.K.; Corey, G.R.; Woods, C.W.; Cabell, C.H.; Reller, L.B.; Cheng, A.C.; Dudley, T.; Oddone, E.Z. Clinical identifiers of complicated Staphylococcus aureus bacteremia. Arch. Intern. Med. 2003, 163, 2066-2072. [CrossRef]

42. Teh, B.W.; Slavin, M.A. Staphylococcus aureus meningitis: Barriers to treatment. Leuk. Lymphoma 2012, 53, 1443-1444. [CrossRef] [PubMed]

43. Aguilar, J.; Urday-Cornejo, V.; Donabedian, S.; Perri, M.; Tibbetts, R.; Zervos, M. Staphylococcus aureus meningitis: Case series and literature review. Medicine 2010, 89, 117-125. [CrossRef]

44. Tunkel, A.R.; Hartman, B.J.; Kaplan, S.L.; Kaufman, B.A.; Roos, K.L.; Scheld, W.M.; Whitley, R.J. Practice guidelines for the management of bacterial meningitis. Clin. Infect. Dis. 2004, 39, 1267-1284. [CrossRef] [PubMed]

45. Darouiche, R.O. Spinal epidural abscess. N. Engl. J. Med. 2006, 355, 2012-2020. [CrossRef] [PubMed]

46. Reihsaus, E.; Waldbaur, H.; Seeling, W. Spinal epidural abscess: A meta-analysis of 915 patients. Neurosurg. Rev. 2000, 23, 175-204. [CrossRef] [PubMed]

47. Herzer, C.M. Toxic shock syndrome: Broadening the differential diagnosis. J. Am. Board Fam. Pract. 2001, 14, 131-136. [PubMed] 
48. DeVries, A.S.; Lesher, L.; Schlievert, P.M.; Rogers, T.; Villaume, L.G.; Danila, R.; Lynfield, R. Staphylococcal toxic shock syndrome 2000-2006: Epidemiology, clinical features, and molecular characteristics. PLoS ONE 2011, 6, e22997. [CrossRef] [PubMed]

49. Lappin, E.; Ferguson, A.J. Gram-positive toxic shock syndromes. Lancet Infect. Dis. 2009, 9, $281-290$. [CrossRef]

50. Fowler, V.G., Jr.; Miro, J.M.; Hoen, B.; Cabell, C.H.; Abrutyn, E.; Rubinstein, E.; Corey, G.R.; Spelman, D.; Bradley, S.F.; Barsic, B.; et al. Staphylococcus aureus endocarditis: A consequence of medical progress. JAMA 2005, 293, 3012-3021. [CrossRef]

51. Tleyjeh, I.M.; Abdel-Latif, A.; Rahbi, H.; Scott, C.G.; Bailey, K.R.; Steckelberg, J.M.; Wilson, W.R.; Baddour, L.M. A systematic review of population-based studies of infective endocarditis. Chest 2007, 132, 1025-1035. [CrossRef]

52. Wang, A.; Athan, E.; Pappas, P.A.; Fowler, V.G., Jr.; Olaison, L.; Paré, C.; Almirante, B.; Muñoz, P.; Rizzi, M.; Naber, C.; et al. Contemporary clinical profile and outcome of prosthetic valve endocarditis. JAMA 2007, 297, 1354-1361. [CrossRef] [PubMed]

53. Alter, P.; Waldhans, S.; Plachta, E.; Moosdorf, R.; Grimm, W. Complications of implantable cardioverter defibrillator therapy in 440 consecutive patients. Pacing Clin. Electrophysiol. 2005, 28, 926-932. [CrossRef] [PubMed]

54. Rodriguez, D.J.; Afzal, A.; Evonich, R.; Haines, D.E. The prevalence of methicillin resistant organisms among pacemaker and defibrillator implant recipients. Am. J. Cardiovasc. Dis. 2012, 2, 116-122. [PubMed]

55. Chitnis, A.S.; Edwards, J.R.; Ricks, P.M.; Sievert, D.M.; Fridkin, S.K.; Gould, C.V. Device-associated infection rates, device utilization, and antimicrobial resistance in long-term acute care hospitals reporting to the National Healthcare Safety Network, 2010. Infect. Control. Hosp. Epidemiol. 2012, 33, 993-1000. [CrossRef]

56. Collignon, P.; Soni, N.; Pearson, I.; Sorrell, T.; Woods, P. Sepsis associated with central vein catheters in critically ill patients. Intensive Care Med. 1988, 14, 227-231. [CrossRef]

57. O'Grady, N.P.; Alexander, M.; Burns, L.A.; Dellinger, E.P.; Garland, J.; Heard, S.O.; Lipsett, P.A.; Masur, H.; Mermel, L.A.; Pearson, M.L.; et al. Guidelines for the prevention of intravascular catheter-related infections. Am. J. Infect. Control 2011, 39, S1-S34. [CrossRef]

58. Muder, R.R.; Brennen, C.; Rihs, J.D.; Wagener, M.M.; Obman, A.; Stout, J.E.; Yu, V.L. Isolation of Staphylococcus aureus from the urinary tract: Association of isolation with symptomatic urinary tract infection and subsequent staphylococcal bacteremia. Clin. Infect. Dis. 2006, 42, 46-50. [CrossRef]

59. Hooton, T.M.; Bradley, S.F.; Cardenas, D.D.; Colgan, R.; Geerlings, S.E.; Rice, J.C.; Saint, S.; Schaeffer, A.J.; Tambayh, P.A.; Tenke, P.; et al. Infectious Diseases Society of America. Diagnosis, prevention, and treatment of catheter-associated urinary tract infection in adults: 2009 International Clinical Practice Guidelines from the Infectious Diseases Society of America. Clin. Infect. Dis. 2010, 50, 625-663. [CrossRef]

60. Crowley, A.L.; Peterson, G.E.; Benjamin, D.K., Jr.; Rimmer, S.H.; Todd, C.; Cabell, C.H.; Reller, L.B.; Ryan, T.; Corey, G.R.; Fowler, V.G., Jr. Venous thrombosis in patients with short- and long-term central venous catheter-associated Staphylococcus aureus bacteremia. Crit. Care Med. 2008, 36, 385-390. [CrossRef]

61. Mostafavifar, A.M.; Guilfoose, J.; Sarwari, A.R. Septic pelvic thrombophlebitis due to Staphylococcus aureus. W. Va. Med. J. 2009, 105, 20-22.

62. Kuehnert, M.J.; Kruszon-Moran, D.; Hill, H.A. Prevalence of Staphylococcus aureus nasal colonization in the United States, 2001-2002. J. Infect. Dis. 2006, 193, 172-179. [CrossRef] [PubMed]

63. Wertheim, H.F.; Melles, D.C.; Vos, M.C.; van Leeuwen, W.; van Belkum, A.; Verbrugh, H.A.; Nouwen, J.L. The role of nasal carriage in Staphylococcus aureus infections. Lancet Infect. Dis. 2005, 5, 751-762. [CrossRef]

64. Brown, A.F.; Leech, J.M.; Rogers, T.R.; McLoughlin, R.M. Staphylococcus aureus Colonization: Modulation of Host Immune Response and Impact on Human Vaccine Design. Front. Immunol. 2014, 4, 507. [CrossRef] [PubMed]

65. Mulcahy, M.E.; McLoughlin, R.M. Host-Bacterial Crosstalk Determines Staphylococcus aureus Nasal Colonization. Trends Microbiol. 2016, 24, 872-886. [CrossRef]

66. Sakr, A.; Brégeon, F.; Mège, J.L.; Rolain, J.M.; Blin, O. Staphylococcus aureus Nasal Colonization: An Update on Mechanisms, Epidemiology, Risk Factors, and Subsequent Infections. Front. Microbiol. 2018, 9, 2419. [CrossRef] 
67. Emonts, M.; Uitterlinden, A.G.; Nouwen, J.L.; Kardys, I.; Maat, M.P.; Melles, D.C.; Witteman, J.; Jong, P.T.; Verbrugh, H.A.; Hofman, A.; et al. Host polymorphisms in interleukin 4, complement factor H, and C-reactive protein associated with nasal carriage of Staphylococcus aureus and occurrence of boils. J. Infect. Dis. 2008, 197, 1244-1253. [CrossRef]

68. Nurjadi, D.; Herrmann, E.; Hinderberger, I.; Zanger, P. Impaired $\beta$-defensin expression in human skin links DEFB1 promoter polymorphisms with persistent Staphylococcus aureus nasal carriage. J. Infect. Dis. 2013, 207, 666-674. [CrossRef]

69. Ruimy, R.; Angebault, C.; Djossou, F.; Dupont, C.; Epelboin, L.; Jarraud, S.; Lefevre, L.A.; Bes, M.; Lixandru, B.E.; Bertine, M.; et al. Are host genetics the predominant determinant of persistent nasal Staphylococcus aureus carriage in humans? J. Infect. Dis. 2010, 202, 924-934. [CrossRef]

70. Zanger, P.; Nurjadi, D.; Vath, B.; Kremsner, P.G. Persistent nasal carriage of Staphylococcus aureus is associated with deficient induction of human beta-defensin 3 after sterile wounding of healthy skin in vivo. Infect. Immun. 2011, 79, 2658-2662. [CrossRef]

71. Vuononvirta, J.; Toivonen, L.; Gröndahl-Yli-Hannuksela, K.; Barkoff, A.M.; Lindholm, L.; Mertsola, J.; Peltola, V.; He, Q. Nasopharyngeal bacterial colonization and gene polymorphisms of mannose-binding lectin and toll-like receptors 2 and 4 in infants. PLOS ONE 2011, 6, e26198. [CrossRef]

72. Van den Akker, E.L.; Nouwen, J.L.; Melles, D.C.; van Rossum, E.F.; Koper, J.W.; Uitterlinden, A.G.; Hofman, A.; Verbrugh, H.A.; Pols, H.A.; Lamberts, S.W.; et al. Staphylococcus aureus nasal carriage is associated with glucocorticoid receptor gene polymorphisms. J. Infect. Dis. 2006, 194, 814-818. [CrossRef] [PubMed]

73. Messaritakis, I.; Samonis, G.; Dimopoulou, D.; Maraki, S.; Papadakis, J.A.; Daraki, V.; Fragaki, M.; Choulaki, C.; Andrianaki, A.M.; Kofteridis, D.P. Staphylococcus aureus nasal carriage might be associated with vitamin D receptor polymorphisms in type 2 diabetes. Clin. Microbiol. Infect. 2014, 20, 920-925. [CrossRef] [PubMed]

74. Kotpal, R.; Bhalla, P.; Dewan, R.; Kaur, R. Incidence and Risk Factors of Nasal Carriage of Staphylococcus aureus in HIV-Infected Individuals in Comparison to HIV-Uninfected Individuals: A Case-Control Study. J. Int Assoc. Provid. AIDS Care. 2016, 15, 141-147. [CrossRef] [PubMed]

75. Bassetti, S.; Wasmer, S.; Hasler, P.; Vogt, T.; Nogarth, D.; Frei, R.; Widmer, A.F. Staphylococcus aureus in patients with rheumatoid arthritis under conventional and anti-tumor necrosis factor-alpha treatment. J. Rheumatol. 2005, 32, 2125-2129. [PubMed]

76. Midorikawa, K.; Ouhara, K.; Komatsuzawa, H.; Kawai, T.; Yamada, S.; Fujiwara, T.; Yamazaki, K.; Sayama, K.; Taubman, M.A.; Kurihara, H.; et al. Staphylococcus aureus susceptibility to innate antimicrobial peptides, beta-defensins and CAP18, expressed by human keratinocytes. Infect. Immun. 2003, 71, 3730-3739. [CrossRef] [PubMed]

77. Gröne, A. Keratinocytes and cytokines. Vet. Immunol. Immunopathol. 2002, 88, 1-12. [CrossRef]

78. Simanski, M.; Rademacher, F.; Schröder, L.; Schumacher, H.M.; Gläser, R.; Harder, J. IL-17A and IFN- $\gamma$ synergistically induce RNase 7 expression via STAT3 in primary keratinocytes. PLoS ONE. 2013, 8, e59531. [CrossRef]

79. Kisich, K.O.; Howell, M.D.; Boguniewicz, M.; Heizer, H.R.; Watson, N.U.; Leung, D.Y. The constitutive capacity of human keratinocytes to kill Staphylococcus aureus is dependent on beta-defensin 3. J. Invest. Dermatol. 2007, 127, 2368-2380. [CrossRef]

80. Zanger, P.; Holzer, J.; Schleucher, R.; Scherbaum, H.; Schittek, B.; Gabrysch, S. Severity of Staphylococcus aureus infection of the skin is associated with inducibility of human beta-defensin 3 but not human beta-defensin 2 . Infect. Immun. 2010, 78, 3112-3117. [CrossRef]

81. Yamasaki, K.; Gallo, R.L. Antimicrobial peptides in human skin disease. Eur. J. Dermatol. 2008, 18, 11-21.

82. Noore, J.; Noore, A.; Li, B. Cationic antimicrobial peptide LL-37 is effective against both extra- and intracellular Staphylococcus aureus. Antimicrob. Agents Chemother. 2013, 57, 1283-1290. [CrossRef] [PubMed]

83. Conti, F.; Spinelli, F.R.; Alessandri, C.; Valesini, G. Toll-like receptors and lupus nephritis. Clin. Rev. Allergy Immunol. 2011, 40, 192-198. [CrossRef] [PubMed]

84. Parker, D.; Prince, A. Staphylococcus aureus induces type I IFN signaling in dendritic cells via TLR9. J. Immunol. 2012, 189, 4040-4046. [CrossRef] [PubMed]

85. Parcina, M.; Miranda-Garcia, M.A.; Durlanik, S.; Ziegler, S.; Over, B.; Georg, P.; Foermer, S.; Ammann, S.; Hilmi, D.; Weber, K.J.; et al. Pathogen-triggered activation of plasmacytoid dendritic cells induces IL-10-producing B cells in response to Staphylococcus aureus. J. Immunol. 2013, 190, 1591-1602. [CrossRef] 
86. Li, J.; Yang, J.; Lu, Y.W.; Wu, S.; Wang, M.R.; Zhu, J.M. Possible Role of Staphylococcal Enterotoxin B in the Pathogenesis of Autoimmune Diseases. Viral Immunol. 2015, 28, 354-359. [CrossRef]

87. Colque-Navarro, P.; Jacobsson, G.; Andersson, R.; Flock, J.I.; Möllby, R. Levels of antibody against 11 Staphylococcus aureus antigens in a healthy population. Clin. Vaccine Immunol. 2010, 17, 1117-1123. [CrossRef]

88. Thwaites, G.E.; Gant, V. Are bloodstream leukocytes. Trojan Horses for the metastasis of Staphylococcus aureus? Nat. Rev. Microbiol 2011, 9, 215-222. [CrossRef]

89. Flannagan, R.S.; Heit, B.; Heinrichs, D.E. Antimicrobial mechanisms of macrophages and the immune evasion strategies of Staphylococcus aureus. Pathogens 2015, 4, 826-868. [CrossRef]

90. Rollin, G.; Tan, X.; Tros, F.; Dupuis, M.; Nassif, X.; Charbit, A.; Coureuil, M. Intracellular survival of Staphylococcus aureus in endothelial cells: A matter of growth or persistence. Front. Microbiol. 2017, 8, 1354. [CrossRef]

91. Zeng, Z.; Surewaard, B.G.; Wong, C.H.; Geoghegan, J.A.; Jenne, C.N.; Kubes, P. CRIg functions as a macrophage pattern recognition receptor to directly bind and capture blood-borne gram-positive bacteria. Cell Host Microbe 2016, 20, 99-106. [CrossRef]

92. Ishikawa, H.; Ma, Z.; Barber, G.N. STING regulates intracellular DNA-mediated, type I interferon-dependent innate immunity. Nature 2009, 461, 788-792. [CrossRef] [PubMed]

93. Woo, S.R.; Fuertes, M.B.; Corrales, L.; Spranger, S.; Furdyna, M.J.; Leung, M.Y.; Duggan, R.; Wang, Y.; Barber, G.N.; Fitzgerald, K.A.; et al. STING-dependent cytosolic DNA sensing mediates innate immune recognition of immunogenic tumors. Immunity 2014, 41, 830-842. [CrossRef] [PubMed]

94. Ma, Z.; Damania, B. The cGAS-STING Defense Pathway and Its Counteraction by Viruses. Cell Host Microbe 2016, 19, 150-158. [CrossRef] [PubMed]

95. Tamayo, R.; Pratt, J.T.; Camilli, A. Roles of cyclic diguanylate in the regulation of bacterial pathogenesis. Annu. Rev. Microbiol. 2007, 61, 131-148. [CrossRef] [PubMed]

96. Scumpia, P.O.; Botten, G.A.; Norman, J.S.; Kelly-Scumpia, K.M.; Spreafico, R.; Ruccia, A.R.; Purbey, P.K.; Thomas, B.J.; Modlin, R.L.; Smale, S.T. Opposing roles of Toll-like receptor and cytosolic DNA-STING signaling pathways for Staphylococcus aureus cutaneous host defense. PLoS Pathog. 2017, 13, e1006496. [CrossRef] [PubMed]

97. Swierstra, J.; Debets, S.; de Vogel, C.; Lemmens-den Toom, N.; Verkaik, N.; Ramdani-Bouguessa, N.; Jonkman, M.F.; van Dijl, J.M.; Fahal, A.; van Belkum, A.; et al. IgG4 subclass-specific responses to Staphylococcus aureus antigens shed new light on host-pathogen interaction. Infect. Immun. 2015, 83, 492-501. [CrossRef] [PubMed]

98. Verkaik, N.J.; de Vogel, C.P.; Boelens, H.A.; Grumann, D.; Hoogenboezem, T.; Vink, C.; Hooijkaas, H.; Foster, T.J.; Verbrugh, H.A.; van Belkum, A.; et al. Anti-staphylococcal humoral immune response in persistent nasal carriers and noncarriers of Staphylococcus aureus. J. Infect. Dis. 2009, 199, 625-632. [CrossRef]

99. Holtfreter, S.; Roschack, K.; Eichler, P.; Eske, K.; Holtfreter, B.; Kohler, C.; Engelmann, S.; Hecker, M.; Greinacher, A.; Broker, B.M. Staphylococcus aureus carriers neutralize superantigens by antibodies specific for their colonizing strain: A potential explanation for their improved prognosis in severe sepsis. J. Infect. Dis. 2006, 193, 1275-1278. [CrossRef]

100. Laudien, M.; Gadola, S.D.; Podschun, R.; Hedderich, J.; Paulsen, J.; Reinhold-Keller, E.; Csernok, E.; Ambrosch, P.; Hellmich, B.; Moosig, F.; et al. Nasal carriage of Staphylococcus aureus and endonasal activity in Wegener s granulomatosis as compared to rheumatoid arthritis and chronic Rhinosinusitis with nasal polyps. Clin. Exp. Rheumatol. 2010, 28 (Suppl. 57), 51-55.

101. Popa, E.R.; Stegeman, C.A.; Kallenberg, C.G.; Tervaert, J.W. Staphylococcus aureus and Wegener's granulomatosis. Arthritis Res. 2002, 4, 77-79. [CrossRef]

102. Popa, E.R.; Tervaert, J.W. The relation between Staphylococcus aureus and Wegener's granulomatosis: Current knowledge and future directions. Intern. Med. 2003, 42, 771-780. [CrossRef] [PubMed]

103. Zycinska, K.; Wardyn, K.A.; Zielonka, T.M.; Demkow, U.; Traburzynski, M.S. Chronic crusting, nasal carriage of Staphylococcus aureus and relapse rate in pulmonary Wegener's granulomatosis. J. Physiol. Pharmacol. 2008, 59 (Suppl. 6), 825-831. [PubMed]

104. Styers, D.; Sheehan, D.J.; Hogan, P.; Sahm, D.F. Laboratory-based surveillance of current antimicrobial resistance patterns and trends among Staphylococcus aureus: 2005 status in the United States. Ann. Clin. Microbiol. Antimicrob. 2006, 5, 2. [CrossRef] [PubMed] 
105. Stegeman, C.A.; Tervaert, J.W.; Sluiter, W.J.; Manson, W.L.; de Jong, P.E.; Kallenberg, C.G. Association of chronic nasal carriage of Staphylococcus aureus and higher relapse rates in Wegener granulomatosis. Ann. Intern. Med. 1994, 120, 12-17. [CrossRef]

106. Salmela, A.; Rasmussen, N.; Tervaert, J.W.C.; Jayne, D.R.W.; Ekstrand, A.; European Vasculitis Study Group. Chronic nasal Staphylococcus aureus carriage identifies a subset of newly diagnosed granulomatosis with polyangiitis patients with high relapse rate. Rheumatology 2017, 56, 965-972. [CrossRef]

107. Kallenberg, C.G.; Stegeman, C.A.; Tervaert, J.W. Staphylococcus aureus, trimethoprim-sulfamethoxazole, and Wegener's granulomatosis. Sarcoidosis Vasc. Diffus. Lung Dis. 1996, 13, 253-255.

108. Rhee, R.L.; Sreih, A.G.; Najem, C.E.; Grayson, P.C.; Zhao, C.; Bittinger, K.; Collman, R.G.; Merkel, P.A. Characterisation of the nasal microbiota in granulomatosis with polyangiitis. Ann. Rheum. Dis. 2018, 77, 1448-1453. [CrossRef]

109. Lamprecht, P.; Fischer, N.; Huang, J.; Burkhardt, L.; Lütgehetmann, M.; Arndt, F.; Rolfs, I.; Kerstein, A.; Iking-Konert, C.; Laudien, M. Changes in the composition of the upper respiratory tract microbial community in granulomatosis with polyangiitis. J. Autoimmun. 2019, 97, 29-39. [CrossRef]

110. Weppner, G.; Ohlei, O.; Hammers, C.M.; Holl-Ulrich, K.; Voswinkel, J.; Bischof, J.; Hasselbacher, K.; Riemekasten, G.; Lamprecht, P.; Ibrahim, S.; et al. In situ detection of PR3-ANCA+ B cells and alterations in the variable region of immunoglobulin genes support a role of inflamed tissue in the emergence of auto-reactivity in granulomatosis with polyangiitis. J. Autoimmun. 2018, 93, 89-103. [CrossRef]

111. Pitzalis, C.; Jones, G.W.; Bombardieri, M.; Jones, S.A. Ectopic lymphoid-like structures in infection, cancer and autoimmunity. Nat. Rev. Immunol. 2014, 14, 447-462. [CrossRef]

112. Hui, Y.; Wohlers, J.; Podschun, R.; Hedderich, J.; Lamprecht, P.; Ambrosch, P.; Laudien, M. Antimicrobial peptides in nasal secretion and mucosa with respect to $S$. aureus colonisation in Wegener's granulomatosis. Clin. Exp. Rheumatol. 2011, 29 (Suppl. 64), S49-S56. [PubMed]

113. Cohen, M.A.; Huband, M.D. Activity of clinafloxacin, trovafloxacin, quinupristin/dalfopristin, and other antimicrobial agents versus Staphylococcus aureus isolates with reduced susceptibility to vancomycin. Diagn. Microbiol. Infect. Dis. 1999, 33, 43-46. [CrossRef]

114. Xu, H.; Tian, R.; Li, Y.; Chen, D.; Liu, Y.; Hu, Y.; Xiao, F. Ribosomal protein L3 mutations are associated with cfr-mediated linezolid resistance in clinical isolates of Staphylococcus cohnii. Curr. Microbiol. 2015, 70, 840-845. [CrossRef] [PubMed]

115. Popa, E.R.; Stegeman, C.A.; Abdulahad, W.H.; van der Meer, B.; Arends, J.; Manson, W.M.; Bos, N.A.; Kallenberg, C.G.; Tervaert, J.W. Staphylococcal toxic-shock-syndrome-toxin-1 as a risk factor for disease relapse in Wegener's granulomatosis. Rheumatology 2007, 46, 1029-1033. [CrossRef] [PubMed]

116. Fijołek, J.; Wiatr, E.; Petroniec, V.; Augustynowicz-Kopec, E.; Bednarek, M.; Gawryluk, D.; Martusewicz-Boros, M.M.; Modrzewska, K.; Radzikowska, E.; Roszkowski-Sliz, K. The presence of staphylococcal superantigens in nasal swabs and correlation with activity of granulomatosis with polyangiitis in own material. Clin. Exp. Rheumatol. 2018, 36 (Suppl. 111), 40-45. [PubMed]

117. Laudien, M.; Häsler, R.; Wohlers, J.; Böck, J.; Lipinski, S.; Bremer, L.; Podschun, R.; Ambrosch, P.; Lamprecht, P.; Rosenstiel, P.; et al. Molecular signatures of a disturbed nasal barrier function in the primary tissue of Wegener's granulomatosis. Mucosal Immunol. 2011, 4, 564-573. [CrossRef]

118. Wohlers, J.; Breucker, K.; Podschun, R.; Hedderich, J.; Lamprecht, P.; Ambrosch, P.; Laudien, M. Aberrant cytokine pattern of the nasal mucosa in granulomatosis with polyangiitis. Arthritis Res. Ther. 2012, 14, R203. [CrossRef]

119. Glasner, C.; de Goffau, M.C.; van Timmeren, M.M.; Schulze, M.L.; Jansen, B.; Tavakol, M.; van Wamel, W.J.B.; Stegeman, C.A.; Kallenberg, C.G.M.; Arends, J.P.; et al. Genetic loci of Staphylococcus aureus associated with anti-neutrophil cytoplasmic autoantibody (ANCA)-associated vasculitides. Sci. Rep. 2017, 7, 12211. [CrossRef]

120. Atzeni, F.; Masala, I.F.; di Franco, M.; Sarzi-Puttini, P. Infections in rheumatoid arthritis. Curr. Opin. Rheumatol. 2017, 29, 323-3304. [CrossRef]

121. Dixon, W.G.; Watson, K.; Lunt, M.; Hyrich, K.L.; Silman, A.J.; Symmons, D.P.; British Society for Rheumatology Biologics Register. Rates of serious infection, including site-specific and bacterial intracellular infection, in rheumatoid arthritis patients receiving anti-tumor necrosis factor therapy: Results from the British Society for Rheumatology Biologics Register. Arthritis Rheum. 2006, 54, 2368-2376. 
122. Winthrop, K.L. Risk and prevention of tuberculosis and other serious opportunistic infections associated with the inhibition of tumor necrosis factor. Nat. Clin. Pract. Rheumatol. 2006, 2, 602-610. [CrossRef] [PubMed]

123. Vaudaux, P.; Grau, G.E.; Huggler, E.; Schumacher-Perdreau, F.; Fiedler, F.; Waldvogel, F.A.; Lew, D.P. Contribution of tumor necrosis factor to host defense against staphylococci in a guinea pig model of foreign body infections. J. Infect. Dis. 1992, 166, 58. [CrossRef] [PubMed]

124. Tabarya, D.; Hoffman, W.L. Staphylococcus aureus nasal carriage in rheumatoid arthritis: Antibody response to toxic shock syndrome toxin-1. Ann. Rheum. Dis. 1996, 55, 823-828. [CrossRef] [PubMed]

125. Varley, C.D.; Deodhar, A.A.; Ehst, B.D.; Bakke, A.; Blauvelt, A.; Vega, R.; Yamashita, S.; Winthrop, K.L. Persistence of Staphylococcus aureus colonization among individuals with immune-mediated inflammatory diseases treated with TNF- $\alpha$ inhibitor therapy. Rheumatology 2014, 53, 332-337. [CrossRef]

126. Goodman, S.M.; Nocon, A.A.; Selemon, N.A.; Shopsin, B.; Fulmer, Y.; Decker, M.E.; Grond, S.E.; Donlin, L.T.; Figgie, M.P.; Sculco, T.P.; et al. Increased Staphylococcus aureus Nasal Carriage Rates in Rheumatoid Arthritis Patients on Biologic Therapy. J. Arthroplast. 2019, 34, 954-958. [CrossRef]

127. Ataee, R.A.; Ataee, M.H.; Alishiri, G.H.; Esmaeili, D. Staphylococcal enterotoxin C in synovial fluid of patients with rheumatoid arthritis. Iran. Red. Crescent Med. J. 2014, 16, e16075. [CrossRef]

128. Ataee, R.A.; Kashefi, R.; Alishiri, G.H.; Esmaieli, D. Assay of Blood and Synovial Fluid of Patients with Rheumatoid Arthritis for Staphylococcus aureus Enterotoxin D: Absence of Bacteria but Presence of Its Toxin. Jundishapur J. Microbiol. 2015, 8, e28395. [CrossRef]

129. Lisnevskaia, L.; Murphy, G.; Isenberg, D. Systemic lupus erythematosus. Lancet 2014, 384, 1878-1888. [CrossRef]

130. Ascherio, A.; Munger, K.L. EBV and Autoimmunity. Curr. Top. Microbiol. Immunol. 2015, 390, 365-385.

131. Rigante, D.; Mazzoni, M.B.; Esposito, S. The cryptic interplay between systemic lupus erythematosus and infections. Autoimmun. Rev. 2014, 13, 96-102. [CrossRef]

132. Esposito, S.; Bosis, S.; Semino, M.; Rigante, D. Infections and systemic lupus erythematosus. Eur. J. Clin. Microbiol. Infect. Dis. 2014, 33, 1467-1475. [CrossRef] [PubMed]

133. Chowdhary, V.R.; Tilahun, A.Y.; Clark, C.R.; Grande, J.P.; Rajagopalan, G. Chronic exposure to staphylococcal superantigen elicits a systemic inflammatory disease mimicking lupus. J. Immunol. 2012, 189, $2054-2062$. [CrossRef] [PubMed]

134. Conti, F.; Ceccarelli, F.; Iaiani, G.; Perricone, C.; Giordano, A.; Amori, L.; Miranda, F.; Massaro, L.; Pacucci, V.A.; Truglia, S.; et al. Association between Staphylococcus aureus nasal carriage and disease phenotype in patients affected by systemic lupus erythematosus. Arthritis Res. Ther. 2016, 18, 177. [CrossRef] [PubMed]

135. Spaan, A.N.; Surewaard, B.G.; Nijland, R.; van Strijp, J.A. Neutrophils versus Staphylococcus aureus: A biological tug of war. Annu. Rev. Microbiol. 2013, 67, 629-650. [CrossRef] 